http://ejournal.ihdn.ac.id

\title{
YOGA DALAM BHAGAVADGITA
}

\author{
Eli Zulaicha \\ Lampung \\ Email: zulicha8912@gmail.com
}

\begin{abstract}
Abstrak:
Bhagavad Gita merupakan hakekat segala pengetahuan Veda dan salah satu diantara Upanisadupanisad yang paling penting dalam kesusastraan Veda. Bhagavad Gita juga menyatakan bahwa yoga merupakan suatu keadaan yang bebas dari penderitaan dan kesedihan. Dalam bhagawad gita \& kitab upanisad; jiva dalam kondisi dosa \& keduniawian adalah disebabkan karena hidup terpisah dan terasing dari roh tertinggi untuk menaklukan sifat jahat dalam diri kita dianjurkan untuk melaksanakan yoga. Agar lepas dari penderitaan dan dosa kita harus mencapai persatuan spiritual persatuan jivatman dengan paratma atman identik dengan kebahagian eternal. Kebahagiaan merupakan cita-cita manusia hidup di dunia, tidak seorangpun bercita-cita menderita. Ada kebahagiaan ragawi/duniawi. Ada kebahagiaan spiritual/rohani. Ada ingin keduanya (lahir \& bathin).
\end{abstract}

Kata Kunci: Yoga, Bhagavad-gita, Jnana, Raja, Karma, Bhakti 


\section{PENDAHULUAN}

Kata Yoga secara harfiah berarti pasangan atau gabungan (kedua kata itu: yaitu yoga dan yug berasal dari akar yang sama) seperti kata agma (re berarti kembali dan ligo berarti: mengikat) memiliki asal mula yang sama (Prabhavananda, 1996:65). Secara etimologi kata, yoga berasal dari bahasa Sansekerta yaitu dari urat kata yuj yang berarti penyatuan, menghubungkan, menjembatani, memperlancar hubungan, dan manunggal. Jadi Yoga merupakan suatu cara untuk menghubungkan diri dengan Tuhan.Apayangdihubungkanatau disatukan? Secara horizontal berarti menyatukan tubuhdengan pikiranjiwa kita dalam keselarasan yang alami. Secara vertikalberarti menghubungkan/ menyatukan kesadaran diri kita dengan Tuhan(spirit

individu/jiwatman dengan spirit universal/paratma atman).

Rsi Patanjali dalam Yoga Sutra menyatakan bahwa Yoga adalah memperbedakan antara subyek dan obyek, purusa (jiwa atau roh) dan prakerti (alam semesta) dengan maksud dan tujuan agar jiwa atau roh dapat bereksistensi secara murni pada dirinya sendiri. Lebih jauh Rsi Patanjali juga mengungkapkan bahwa yoga dimaksud adalah suatu upaya secara methadikal untuk mencapai kesempurnaan jiwa, dengan jalan mengontrol berbagai unsur alamiah manusia, baik fisik (badan jasmani) maupun kejiwaan. Seseorang yang mencari penyatuan ini disebut dengan yoga atau yogi. "yogascitta vrtti nirodhah"(yoga sutra I.2) yoga adalah membatasi/ penghentian gerak/gelombang pikiran. Pikiran, karena fluktuasinya dapat mengaburkan pikiran itu sendiri yang sebenarnya:tenang, seimbang \& terfokus. Ajaran Yoga merupakan bagian dari 6 filsafat diantaranya yaitu Nyaya, Waisesika, Samkhya, Yoga, Mimamsa dan Wedanta. Dimana ajaran Samkhya dan Yoga sering dibicarakan secara berurutan karena memiliki kesamaan). Dalam melaksanakan Yoga, Rsi Patanjali mengajarkan Astangga Yoga yaitudelapan macam disiplin untuk memungkinkan seseorang dapat mencapai tingkat kesucian batin dan kesempurnaa citta. Delapan disiplin itu adalah: Yama, Niyama, Asana, Pranayama, Pratyahara, Dharana, Dhyana dan Samadhi

Yama dan Niyama membentuk disiplin etika yang memurnikan hati. Yama terdiri atas Ahimsa (tanpa kekerasan), Satya (kejujuran), Brahmacarya

(membujang; pengendalian hawa nafsu), Asteya (tidak mencuri) dan Aparigraha (tidak menerima pemberian kemewahan, semua kebajikan berakar pada Ahimsa. Niyama adalah kepatuhan, dan tersusun atas Sauca (pemurnian dalam dan luar), Santosa (kepuasan), Tapas (kesederhanaan), Swadhyaya (belajar kitab suci dan penguncaran mantra) dan Iswarapranidhana (berserah diri kepada Tuhan). Mereka yang mantap dalam Yama dan Niyama akan cepat maju dalam melaksanakan Yoga. Asana, pranayamadan pratyahara merupakanperlengkapa $\mathrm{n}$ pendahuluan dari Yoga. Asana adalah sikap badan yang mantap. Pranayama adalah pengaturan nafas yang menghasilkan ketenangan dan kemantapan pikiran serta kesehatan yang baik. Pratyahara adalah penarikan indriya-indriya dari obye k- obyeknya. Dharana adalah konsentrasi pikiran pada sesuatu obyek, atau cakra dalam atau Ista Dewata. Lalu menyusul Dhyana, atau meditasi, yaitu pengaliran yang tak henti-hentinya dari pemikiran sehubungan satu obyek, yang nantinya membawa pada keadaan samadhi. Saat seperti ini yang bermeditasi dan yang dimeditasikan menjadi satu. Semua wrtti atau gejolak pikiran mengendap dan pikiran kehilangan fungsinya. Segala samskara, kesan-kesan dan wasana (kecenderungan dan keinginan halus) terbakar sepenuhnya dan yoga terbebas dari kelahiran dan kematian. Ia mencapai kaiwalya atau pembebasan akhir (Sivananda, 2003:136-137).

\section{PEMBAHASAN}

Bhagavadgita adalah sebagai Pancamo Veda yang bersifat suplemen. Penggunaan istilah Upanisad pada beberapa bab di dalam Bhagavadgita menunjukkan bahwa Bhagavadgita adalah sebuah Upanisad dan upanisad itu sendiri adalah Veda yang tergolong Sruti. Dengan penunjukan itu tidaklah keliru penyimpulan 
beberapa pemikir Hindu yang mengatakan Bhagavadgita adalah Veda ke 5. Bhagavadgita adalah ajaran mistik. Ilmu mistik di dalam agama Hindu dikenal dengan Raja Yoga, bertujuan untuk menguak tabir Rahasia Ketuhanan sehingga dengan demikian mudahlah bagi umatnya melaksanakan jalan lintas itu menuju kekekalan Brahman atau Nirvana Brahman atau Moksa. Ini pula yang menyebabkan Bhagavadgita dikenal sebagai kitab Gita Rahasia.

Bhagavadgita adalah kitab Yoga karena semua bab disebut ajaran Yoga. Yoga adalah satu sistim dan juga satu metode menghubungkan diri atau bersembah kepada Tuhan agar mendapat rakhmat dari padanya. Bhagavadgita adalah kitab Tattva Darsana yang membahas konsepsi filsafat Samkhya dan Yoga, dan karena itu cara pandangnya penyajian materinya mendekati sistim filsafat Samkhya dan Yoga. Istilah inipun disebutkan di dalam Bhagavadgita itu.

Bhagavad Gita terdiri dari dua kata yaitu Bhagavad dan Gita yang berarti "Lagu dari Tuhan". Bagaimanapun juga bukan lirik tetapi puisi filsafat, yang ditulis oleh Rsi Vyasa, pengumpul dari cerita Mahabharata. Gita merupakan panduan manual: "Siapakah kita? Mengapa kita terlahir? Apa tujuan dari hidup kita? Apa yang harus kita lakukan jika tugas kita menimbulkan konflik dengan orang lain" Pertanyaan ini dan pertanyaan yang lain yang muncul dan dijawab dalam Bhagavad Gita. Para cendekiawan mengatakan bahwa ada tiga rahasia yang terdapat dalam Gita yaitu yangpertama, seseorang harus melakukan semua tugasnya di dunia, meninggalkan semua ikatan untuk mendapatkan hasil dari tindakan kita. Yang kedua, seseorang harus membedakan antara dirinya dan yang bukan dirinya. Yang ketiga, seseorang harus menyadari bahwa semuanya yang ada, bergerak atau tidak bergerak, terlihat ataupun tidak terlihat, tiada bukan adalah Brahman. Bhagavad Gita menganjurkan empat jalan untuk mencapai kebebasan (moksa) terdiri dari: tindakan (Karma Yoga), meditasi (Raja Yoga), pengabdian (Bhakti Yoga), dan pengetahuan (Jnana Yoga). Jalan ini bukanlah jalan utama tetapi berhubungan dan mengarahkan seseorang pada tujuan yang sama. Semua jalan membutuhkan kehidupan yang bermoral dan disiplin diri. Seorang individu dapat menemukan keberadaan dari Kenyataan Tuhan (sebagai intisari dari dirinya) dengan mengikuti satu atau lebih jalan dibawah bimbingan dari seorang guru yang bermutu. Seorang pemuja dapat mengikuti satu atau jalan yang lain bergantung dari sifat dan keinginannya (Pandit, 2006:88-93).

\subsection{Pokok-Pokok Ajaran Bhagavad Gita}

Untuk dapat memahami pokok-pokok ajaran yang terdapat di dalam Bhagavadgita, kiranya perlu diadakan penataan struktural keseluruhan isi Bhagavadgita. Keseluruhan isi Bhagavadgita terbagi atas 18 bab dimana tiap-tiap bab membahas secara khusus. Keseluruhan isi bab Bhagavadgita dapat disimpulkan pokok-pokok pikiran sebagai berikut:

Bab I, memulai pandangan ajaran bersandar pada dialektika teori konflik mengenai hakekat yang dialami oleh manusia. Arjuna Visada Yoga atau ajaran keragu-raguan yang timbul pada diri Arjuna setelah menyadari akibat peperangan yang dapat terjadi dinilai bertentangan dengan ajaran agama.Termasuk di dalam bab I adalah gambaran situasi di padang Kuru, tempat terjadinya perang saudara. Masalah yang dihadapi oleh Arjuna adalah pertentangan "Nilai Religi" dimana dasar-dasar agama mengajarkan:

1. Ajaran ahimsa

2. Larangan membunuh guru sebagai dosa besar (maha pataka)

3. Ajaran Vairagya sebagai sistim pencapaian tujuan moksa

4 Timbulnya kemerosotan moral dan musnahnya tradisi leluhur sebagai ekses terjadinya peperangan.

5. Timbulnya kekacauan dalam sistim Varnasrama-dharma termasuk persepsi timbulnya kekacauan dalam jatidharma dan dharma.

Semua analisa pemikiran Arjuna yang dilihat secara empiris pada hakekatnya banyak terjadi pertentangan di dalam penerapan ajaran moral agama sehingga bila tujuan hidup agama itu 
harus direalisir, apapun dalihnya peperangan itu bertentangan dengan agama. Namun Arjuna menyadari pula bahwa ia tidak mengingkari kemungkinan berbagai alternatif namun untuk memantapkannya arjuna mengharapkan bimbingan dari Krsna untuk keluar dari kebingungan itu.

Bab II, Krsna yang menanggapi pandangan dan perasaan yang dialami oleh Arjuna, menjelaskan dasar pemikiran sebagai berikut:Konflik pribadi yang terjadi pada setiap diri manusia pada hakekatnya bersumber pada beberapa sebab:

1. Sifat lemah yang ada pada setiap diri manusia yang mudah menyerah pada keadaan. Sifat lemah ini disebut "anarya". Sifat putus asa seperti ini pada hakekatnya bertentangan dengan ajaran agama Hindu yang mewajibkan agar tidak berputus asa dalam segala hal.

2. Kebodohan atau Avidya pada hakekatnya menimbulkan kesalah pengertian tentang ajaran serta kenyataan. Demikian pula masalah pencapaian tujuan yang disebut Svarga dan moksa bersumber pada kesalah pahaman yang mencakup masalah kirti dan yasa.

Oleh karena Krsna melihat masalah yang dihadapi oleh Arjuna bersumber pada hakekat diatas maka usaha pertama yang diambil oleh Krsna adalah mencoba menjelaskan hakekat hidup dan tujuan hidup yang sebenarnya sebagaimana diajarkan di dalam agama Hindu dengan ajaran Samkhya-Yoga, sebagai judul yang diberikan dalam Bab II.Pada hakekat apa yang disebut Samkhya-Yoga adalah ajaran kefilsafatan (tattva darsana).

a. Samkhya merupakan ajaran rasionalisme atau jnana-yoga.

b. Yoga merupakan ajaran disiplin moral sebagai upaya untuk mencapai tujuan hidup beragama (moksa).

Kedua dasar ajaran itu didasarkan pada konsep Upanisad yang mengutarakan bahwa tujuan hidup manusia pada hakekatnya dapat dicapai melalui:

1. Pravrtti marga

2. Nivrtti marga

Kedua dasar ajaran itu hendaknya dipahami dengan tepat agar tujuan hidup beragama dapat dicapai dengan baik, yaitu dharma-artha-kama moksa.

Bab III. Membahas dasar-dasar pengertian Karma Yoga yang dibedakan dari ajaran Samnyasa Yoga. Kedua ajaran ini dibahas dari aspek ajaran Samkhya dan Yoga. Dengan memahami kesalah pengertian Karma Yoga sebagai satu sistim yang dianggap bertentangan dengan sistim Samnyasa, Krsna mencoba menegaskan makna ajaran Karma Yoga secara lebih mendetail, yang keseluruhan pada hakekatnya dibahas dalam Bab III, Bab IX. Pada Bab II telah dikemukakan pentingnya ratio atau keilmuan sebagai pangkal tindak kegiatan. Jnana dengan ajaran Jnana Yoga merupakan anti ajaran Samkhya, sebaliknya karma atau tindakan tidak harus berarti sama dengan jnana. Tentang karma ini dibedakan dalam Bhagavadgita ke dalam dua bentuk, yaitu:

1. Subha karma perbuatan yang baik

2. Asubha karma perbuatan yang tidak baik Adapun perbuatan yang tidak baik dibedakan pula antara dua macam, yaitu:
a. Akarma
b. Vikarma

Dengan demikian terdapat tiga macam bentuk sikap tindak kegiatan,yaitu:

1. Karma yaitu perbuatan baik.

2. Akarma yaitu perbuatan tidak berbuat.

3. Vikarma yaitu perbuatan yang keliru.

Apa yang diharapkan dari ajaran Karma Yoga ini adalah tercapainya tujuan, yang merupakan kebebasan, yaitu moksa atau siddhi (kesempurnaan). Ada dua hakekat pengertian kata "karma" yang berkembang di dalam Bhagavadgita, yaitu:

a. Karma dalam arti ritual atau yajna

b. Karma dalam arti tingkah laku perbuatan.

Ini tampak jelas uraian III.10 yang menghubungkan arti karma dengan penciptaan alam semesta yang dilakukan pada permulaan 
penciptaan oleh Tuhan Yang Maha Esa. Bila Tuhan dalam permulaan penciptaan itu menciptakannya bukan untuk kepentingan dirinya maka demikian pula dalam hukum kerja itu agar didasarkan pada azas ketidak terikatan untuk kepentingan pribadi seseorang yang berbuat, melainkan agar didasarkan atas dharma yang menjelma dari bentuk hukum hak dan kewajiban.

Dengan demikian maka azas "vairagya" sebagai satu ajaran, mendorong pelakunya berbuat sekedar karena kewajiban untuk mencapai prestasi yang lebih baik. Ini harus dilakukan baik rutin maupun insidentil sehingga kekarya-annya itu akan mempunyai nilai guna. Soal pahala atau akibat yang timbul adalah hak yang pasti dan tak usah dicari-cari, yang tentunya akan diperoleh.

Bab IV, menguraikan tentang Jnana Yoga, yang telah berkali-kali disampaikan Sri Krsna kepada umat manusia untuk menjadikannya manusia-manusia bijak dalam tujuan pengembaraan hidupnya. Bahkan manakala dharma terancam dan adharma merajalela, beliau sendiri turun ke dunia dengan mengenakan badan jasmani untuk melindungi ajaran dharma dari kehancuran, serta untuk melindungi orang-orang bajik. Disamping itu ajaran tentang varnasrama dharma, serta berbagai jalan yang ditempuh manusia dalam rangka pencapauannya yang tertinggi juga diuraikan dalam Bab ini. Jnana Yoga sebagai satu-satunya cara mencapai kelepasan (moksa), sebagai thema utama dalam sebagian besar kitab Upanisad, juga kembali ditekankan disini, disamping kegiatan kerja tanpa pamrih yang tidak membelenggu, demikian pula kurban kebijaksanaan sebagai kurban tertinggi, karena kebijaksanaan itu sendiri akan membakar habis segala dosa dan akibat dari perbuatan. Selanjutnya secara panjang lebar Krsna juga menjelaskan kepada Arjuna kaitan Jnana Yoga ini dengan Yoga lain, yang memberikan kemantapan kepada Arjuna dalam mengemban tugas sebagai seorang ksatriya dalam menghadapi pertempuran ini.

Bab V, Bhagavadgita dengan judul Karma Samnyasa Yoga, pada intinya mencoba memperbandingkan antara dua sistem jalan menuju kesempurnaan, yaitu karma samnyasa disatu pihak dan Yoga dibagian kedua. Penjelasan bab V merupakan pengembangan pengertian jaran yang telah dijelaskan dalam bab IV tentang arti Jnana Yoga. Apa yang Arjuna sebagai calon siswa ingin ketahui dari Gurunya adalah penjelasan yang terang mengenai jawaban atas pertanyaan, yaitu mana yang lebih baik membebaskan diri dari kerja (karma samnyasa) atau kerja tanpa kepentingan pribadi atau tanpa motif untuk mencapai keuntungan pribadi. Sistem kerja yang kedua di dalam bab $\mathrm{V}$ ini disebut Yoga dan dijelaskan bahwa sistem kedua adalah lebih baik. Penampilan kedua macam pertanyaan ini tentunya dilakukan pada satu pengertian dengan mengingat sistem catur asrama (brahmacari, grhastha, vanaprastha, samnyasa)

Dalam yoga, karma itu tetap ada tetapi bukan dimotivasi untuk kepentingan pribadi melainkan pelepasan keakuan terhadap bendabenda duniawi dengan memusatkan perhatian pada kebaktian kepada Tuhan Yang Maha Esa dengan bersamadhi. Yoga artinya menghubungkan (yuj) pikiran kepada Tuhan sehingga segala sifat hakiki Tuhan dapat direflesikan ke dalam jiwa dan dengandemikian maka berbuat itu tidak terikat oleh diri pribadi tetapi adalah karena kehendak Ilahi.

Bab VI, adalah uraian tentang makna Dhyana Yoga sebagai satu sistem dalam Yoga. Bab VI adalah dialog lanjutan dari bab V tentang Yoga. Yoga mengajarkan delapan macam disiplin untuk memungkinkan seseorang dapat mencapai tingkat kesucian batin dan kesempurnaa citta. Delapan disiplin itu adalah: Yama, Niyama, Asana, Pranayama, Pratyahara, Dharana, Dhyana dan Samadhi. Ajaran Dhyana Yoga atau Dhyana dalam sistem Yoga inilah yang dijelaskan oleh Krsna kepada Arjuna.

Agar seseorang dapat melakukan Yoga dan bermeditasi yang baik semua syarat harus dipenuhi. Apa yang diajarkan dengan sikap duduk yang baik seperti badan, leher, dan kepala supaya tegak dan duduk diam tidak bergerak, merupakan sikap Asana. Sikap Asana yang baik menyebabkan orang dapat mudah melakukan konsentrasi pikiran atau Dhyana. Walaupun demikian Arjuna yakin bahwa pikiran itu bersifat seperti binatang liar 
yang sukar untuk dijinakkan sehingga sangat sulit untuk dapat meninggalkan pikiran dalam mencapai tujuan. Kesemuanya ini dijelskan secara singkat, yang pada intinya adalah bagaimana membiasakan putusan uang baik melalui Yama dan Niyama brata. Walaupun demikian Krsna juga mengakui kesulitan dan karena itu alternatifnya adalah mengarah pada perbuatan kebajikan. Manusia akan lahir kembali ke dunia sesudah sampai surga bila sudah selesai masanya penikmatan hasil kebajikan itu, dan ini akan berulang sampai mereka berhasil melepaskan diri mereka dari sarang laba-laba karma, yaitu kelak kalau mereka telah mencapai nirvana atau moksa atau Brahma Nirvana. Seorang Yogi menurut Krsna adalah lebih besar dari pertapa maupun sarjana dan lebih besar pula artinya dari pendeta yang melakukan upacara yajna.

Bab VII, ininya adalah membahas Jnana dan Vijnana. Jnana artinya ilmu pengtahuan dan Vijnana adalah serba tahu dalam pengetahuan itu. Karena bab ini merupakan lanjutan bab VI tentang Dhyana untuk sampai pada tingkat Samadhi, maka perhatian pembahasan adalah terletak pada tujuan obyek Dhyana yaitu Tuhan Yang Maha Esa, yang di dalam agama disebut Para Brahman-Para Atman-Para Isvara dan lain-lainnya oleh karena itu Krsna mulaimenjelaskan makna pengertian atman dan hubungannya denganPara Atman atau Brahman yang absolute. Alam semesta dengan segala bentuk ciptaan itu disebut bhuta, yang mempunyai lima komponen dasar yang disebut panca mahabhuta, terdiri dari Prthivi (tanah), Apah (air), Teja atau Agni (api, panas), Vayu (angin), Akasa (eter).

Kelima unsur dasar itu timbul dari prakrti dan sebagai akibat evolusi dari prakrti. Disamping unsur materi terdapat unsur rohani yang disebut atman atau jiwa yang menyebabkan timbulnya ciptaan (srsti)

Jiwa atau atman adalahbagian dari Brahman dan perlu disadari adalah hubungan pengertian antara atman dengan Brahman. Di dalam melakukan samadhi, hakekat inilah yang harus dicapai dalam pengertian dan makna aksara mantra AUM atau Omkara sebagai manifestasi wujud abadi. Disamping itu Krsna juga mulai menyinggung pengertian triguna sebagai hakekat sifat dasar dari prakrtin sehingga timbulnya proses evolusin sebagai akibat ketidakseimbangan triguna. Ketidak sadaran dan kekeliruan pandngan pada Manusia adalah karena kekuatan maya sehingga salah identifikasi manusia dan menyamakan atma dengan prakrti. Pemahaman keliru ibarat orang melihat cermin itu berbeda. Inilah yang disebut kekuatan maya. Bila orang menyadari hal ini maka orang akan mulai dapat mengarahkan pikirannya secara benar dan dari sini akan melihat mengapa "aham" (aku) itu adalah Brahman (yang absolut Transendental), dan ada pula pada setiap mahluk.

Bab VIII, adalah Aksara Brahma Yoga, yaitu tentang hakekat sifat kekekalan Tuhan yang Maha Esa. Aksara berarti kekal. Inti bab VIII adalah bertujuan menjawab pertanyaan Arjuna tentang Brahman-Adhyatma dan karma. Demikian pula tentang adhibhuta, adhidiva, adhiyajna dan hakekat kematian. Yang sangat menarik dalam bab VIII adalah cara pendekatan pengertian yang dapat memberi uraian yang jelas tentang Brahman dengan adhatman yang pada hakekatnya adalah sama dengan Parama Atman.

Sebagaimana atman mempunyai basis adhatman (Brahman) demikian pula tentunya hakekat bhuta, yaitu panca mahabhuta dengan adhibhuta itu, yang dalam sistem samkya disebut prakrti dan pradhana dalam sistem Vedanta.

Dari pertanyaan Arjuna yang masih mendapt penyorotan khusus adalah pertanyaan dan pengertian tentang adhiyajna dan adhidaivata (adhidaibata). Di dalam Veda kita dapat penjelsan tentang penciptaan alam semesta di mulai dari proses mahayajna dimana mahapurusa menciptakan segala ciptaan melalui yajna. Yajna ini merupakan awal dan karena itu cukup beralasan kalau arjuna mempergunakan istilah adhiyajna.

Bab IX, membahas hakekat dasar-dasar ajaran Raja Yoga dengan judul Raja Vidya RajaGuhya Yoga.

Hakekat raja hanya sebagai istilah untuk menunjukkan raja dari semua ilmu (vidya) yaitu ajaran Ketuhanan. Hal ini adalah kerana segala apa 
yang ada bersal dari Tuhan dan karena itu mempelajari Ketuhanan Yang Maha Esa dianggap sangat mulia dan ilmunya adalah tertinggi dari semua ilmu. Artinya ilmu-ilmu lainnya bersifat suplemen. Dalam hubungan ini Krsna tidak saja menjelskan arti dan kedudukan Tuhan sebagai Brahman, sebagai Bapak atau sebagai Pelindung dan Pencipta tetapi juga bagaimana alam semesta ini diciptakan. Bila hendak melakukan bhakti atau sembahyang maka tujuan sembahyang adalah kepada Yang Maha Esa itu, apapun nama atau gelar yang diberikan kepadaNya. Semua harus mencari perlindungan kepadaNya dan dengan demikian Krsna mengajarkan Tuhan sebagai poros dari semua ciptaan dan kebaktian.

Bab X, Vibhuti Yoga mencoba memberi penjelasan tentang sifat hakekat Tuhan yang absolut secara empiris dimana disimpulkan hakekat absolut transendental sebagai akibat hakekat tanpa permulaan-pertengahan-akhir.

Demikian pula manifestasi Brahman dalam alam semesta, sebagai kitab suci, sebagai Devata, sebagai manusia dan sebagai huruf yang kesemuanya memerlukan pengertian dan dasardasar keimanan yang kuat.

Bab XI, Visvarupa Darsana Yoga sebagai uraian penjelsan lebih lanjt dari ajaran Vibhuti Yoga mencoba menjelaskan bentuk manifestasinya secara nyata dengna menyadari persamaan itu maka terjadwalah misteri yang ada pada Ketuhanan Yang Maha Esa sebagai hakekat Yang Maha Ada.

Bab XII, Bhakti Yoga. Di dalam bhakti yoga dimana mansuia bersembah sujud kepada Tuhan Yang Maha Esa ada dua hal yang ingin dipertanyakan oleh Arjuna, yaitu:

1. Menyembah Tuhan dalam wujudnya yang abstrak

2. Menyembah Tuhan dalam wujud nyata, misalnya mempergunakan nyasa atau pratima berupa arca atau mantra.

Terhadap kedua penyataan ini Krsna menegaskan bahwa kedua-duanya itu baik. Penyembahan Tuhan dalam wujud abstrak, yaitu dengan menanggalkan pikiran kepada yang disembah adalah amat baik namun hambatan dan kesulitan itu tetap banyak karena Tuhan yang tanpa wujud, kekal abadi, tak berubah dan sebagainya, sangat sulit untuk dicapai oleh akal pikiran dan karena itu praktis sangat sukar. Sebaliknya dengan Yoga biasa dimana diperlukan sarana pratima atau arca akan lebih mudah untuk mewujudkan rasa bhaktinya. Tetapi itu belum nyata.

Bab XIII, yaitu Ksetra_Ksetrajna vibhaga Yoga merupakan bab yang membahas hakekat Ketuhanan Yang Maha Esa yang dihubungkan dengan hakekat purusa dan prakrti (pradhana) sebagai nama rupa. Kebutuhan nama rupa yang digelari dengan purusa dan prakrti adalah untuk memberi landasan dalam menjelskan bagaimana kita dapat mengenal Tuhan Yang Maha Esa sebagai hakekat yang Maha mengetahui dan bagaimana pula proses kejadian ini dari Purusa dan prakrti sampai pada segala untuk ciptaan alam semesta melalui proses kejadian dari 24 macam elemen. Disamping itu bab XIII ini pula bertujuan untuk menjelskan sifat yang dimiliki oleh orang yang dapat dikategorikan sebagai arif bijaksana. Untuk itu Krsna memberi uraian tentang kebaikan dari sifat rendah hati, tidak cepat marah, sabar, tawakal, adil, jujur, beriman, suci lahir bathin dengan selalu mengendalikan pikiran, tutur kata dan tingkah laku sehingga terkendalinya Ego, dan makin bertambah baiknya budi pekerti manusia.

Bab XIV, membahas triguna, sesuai dengan judulnya yaitu Guna Traya (tiga macam guna). Ketiga macam guna yang dimaksud yaitu sattvam-rajas-tamas. Manifestasi guna pada diri seseorang dapat dilihat dari bentuk tingkah laku mereka sebagai refleksi dari triguna. Sebaliknya yang menjadi tujuan dari pembahasan guna traya ini adalah bagaimana seseorang dapat mengatasi ketiga guna itu sehingga dapat mengatasi segalagalanya. Khusus untuk sifat-sifat seseorang yang telah dapat mengatasi pengaruh triguna digambarkan sebagai seseorang yang memiliki watak tidak benci, selalu hidup dalam keadaan tenang tidak memiliki pertentangan bathin sebagai akibat pengaruh sifat-sifat yang bertentangan dalam diri pribadinya, tidak mudah goyah atau berubah-ubah pendirian melainkan selalu mengabdi dab berbakti tanpa pamrih. 
Bab XV, membahas pengertian purusa sebagai asal dari semua ciptaan. Purusattama atau purusa uttama adalah purusa yang Maha tinggi, yaitu hakekat Ketuhanan Yang Maha Esa dan yang di dalam uraian ini tidak lain dari hakekat Aku yang transendental. Ia adalah Brahman. Di dalam pembahasan ini untuk mengambarkan dengan jelas agar diketahui hakekat hubungan antar Sang Pencipta dengan segala ciptaannya. Krsna mengibaratkannya sebagai pohon asvattha atau ficus religiose (semacam pohon beringin) dimana kalau pohon itu berakar, berbatang, berdaun dan lain-lain maka akarnya (asalnya) adalah purusa itu sedangkan kejadian lainnya adalah batang dahan dan daun-daunnya. Tetapi kita juga diajarkan bahwa Tuhan itu ada diatas dan karena itu pohon asvattha itu dikatakan akarnya ada diatas yang kemudian batangnya yang berjurai ke bawah dengan sifat-sifatnya adalah semua ciptaannya. Purusottama adalah adhyatman yang berarti atma yang menghidupi mahluk ciptaan itu bertebaran ke bawah.

Bab XVI, Daivasura Sampad vibhaga Yoga pada intinya membahas hakekat tingkah laku manusia yang dikenal sebagai perbuatan baik dan perbuatan buruk. Kedua hal ini merupakan inti pertanyaan Arjuna.

Di dalam menjawab pertanyaan itu Krsna menggambarkan tentang sifat-sifat yang disebut sifat Devata dan sifat-sifat jahat sebagai sifat-sifat raksasa atau asura.

Mulai dari syair 1 sampai 3 adalah gambaran tentang sifat-sifat mulia sedangkan sifatsifat asura adalah berlawanan dan diperinci dalam syair 4. Dikemukakan pula bahwa secara impiris tidak ada manusia yang hidupnya sempurna dan karena itu Krsna mendesak agar Arjuna atau siapa saja yang tidak berputus asa dan tidak pula merasa takut.

Dalam uraiannya apa yang disebut dalam syair 8 terdapat paham lokayatika atau carvaka sebagai filsafat hedonis telah dikenal pula yang di dalam agama Hindu dtentang sebagai filsafat amoral. Dari syair 24, yang berakhir pada bab XVI Krsna menegaskan agar kitab sastra dan Veda supaya dipedomani. Kitab sastra adalah Kitab smrti sebagai lawan dari Kitab Sruti.

Bab XVII, sesuai menurut judulnya yaitu sraddha Traya Vibhaga Yoga bertujuan untuk meyakinkan agar berkeyakinan akan tiga hal yaitu triguna. Penekanan ini sebagai penanggilangan adalah untuk menyakinkan pelayan sikap mental yang positif terhadap pandangan pengaruh yang timbul karena triguna dengan tujuan untuk mencapai kesempurnaan hidup. Bagian ini merupakan landasan etika atau dharma. Keyakinan yang kedua adalah hakekat ucapan AUM (OM) Tat Sat sebagai pengakuan adanya Tuhan Yang Maha Ada tiada lain kecuali Yang Maha abadi yang disebut pula aksara Brahman. Yang ketiga adalah keyakinan akan tercapainya moksa yang juga disebut brahman nirvana.

Bab XVIII, yaitu bab terakhir adalah Samnyasa Yoga. Bab ini merupakan kesimpulan dari semua ajaran yang menjadi inti tujuan pelaksana agama yang tertinggi yaitu brahma nirvana sebagai Sumumbonum dengan kesimpulan ini maka jelas kepada kita bahwa Bhagavadgita mencoba mendorong Arjuna untuk bertindak tanpa ragu dan tidak mengikat diri pada apa kewajiban itu dan apa pula akibatnya, melainkan bertindak dan pasrah kepada Tuhan sebagai Yang Maha mengatur sehingga dengan demikian rasa berdosa itu dapat diatasi. Bab XVIII ini merupakan bab yang terpanjang. (Pudja, 1999)

\subsection{Esensi Yoga Dalam Bhagavad Gita}

Kata yoga memberi definisi tentang cara bagaimana Tuhan itu bisa bersatu dengan manusia. Banyak cara yang mungkin ditempuh oleh manusia untuk mencapai tujuan itu. "Banyak ada agama, banyak juga ada jalan". Filsafat Hindu mengenal empat cara pokok (yoga) untuk mencapai tujuan itu. Cara itu adalah Jnana yoga, Karma yoga, Bhakti yoga dan Raja yoga. Masing-masing yoga merupakan cara tersendiri untuk mendekatkan diri pada Tuhan dan ketika tujuan akhir itu tercapai, agaknya keempat yoga itu berpadu menjadi satu. Cinta kasih yang tertinggi, ilmu pengetahuan yang hebat, semadi yang sejati, tindakan yang benar, dan paling mulia pada akhirnya sama dan tidak dapat dibedakan antara satu dengan yang lainnya. 
Gita menuntut bahwa cara-cara itu harus diikuti dan dipadukan bukan saja saat tujuan akhir itu tercapai, melainkan dipakai sebagai cara dalam menempuh cita-cita itu. Manusia mempunyai kemampuan, alasan, keinginan, emosi yang kompleks, gerak hati untuk bertindak, dan dia harus berusaha menyatu dengan Tuhan melalui cara-cara yoga itu. Dia harus aktif dan juga rajin bersemedi, dia harus mengolah kecerdasannya dan menemukan ilmu pengetahuan yang tertinggi juga mempererat cinta kasih pada Yang Maha Kuasa. Seperti itulah cita-cita yoga yang sebagaimana di ajarkan dalam Gita. (Prabhavananda, 1995: 66-67)

\section{Jnana Yoga}

Jnana Yoga adalah jalan pengembangan kebijaksanaan spiritual. Ini merupakan jalan bagi kaum inteletual. Intelek difokuskan untuk menjawab pertanyaan, "Siapakah aku?". Sang yogi menganalisa semua unsur dirinya satu persatu dan menghancurkan kebodohan. Ia mencapai kesadaran atman, bersinar dengan cahaya kebijaksanaan. Pencapaian ini diperoleh melalui belajar dan meditasi (Kamajaya, 1998:22). Jnana Yoga, secara harfiah berarti cara untuk menyatukan diri dengan Tuhan melalui ilmu pengetahuan. Ini telah mengandung arti suatu cara analisis yang intelektual. Yang mengarah pada satu hal tentang Tuhan yang paling dekat. Anubhuti yang bersifat paling super dan kekal abadi merupakan bagian yang paling medalam pada diri manusia dan alam semesta. Pemikiran filosofi tidak dinyatakan secara langsung, rasionalisasi pemikiran belaka, tetapi lebih dari itu bahwa manusia yang tanpa pertolongan orang intelek tidak akan dekat dengan Tuhan. Sebagai tambahan, bahwa perubahan kehidupan dan prilaku, perubahan jiwa amat diperlukan sebelum penjelmaan Tuhan atau Diri itu dapat dicapai. Maka Gita mengatakan "Ada yang menganggap diri itu bagus sekali" yang lainnya mengatakannya sebagai sesuatu yang bagus sekali. Yang lain lagi mendengarkannya sebagai suatu keajaiban. Dan masih ada yang lain walaupun mendengar, sama sekali tidak mengerti dengan Diri itu (II, 29).

Untuk mencapai kesadaran yang paling dekat ini dan memahami tentang Diri, Jnana yoga mengajarkan ajaran-ajaran tertentu untuk dilatih setelah proses pemikiran. Pada permulaan sekali, ahli fisafat harus belajar membedakan antara yang nyata dan yang tidak nyata. Pada pembukaan pada bab Gita itu, dijelaskan tentang proses perbedaan ini.

\section{Na sato widyate bhawo \\ Na bhawo widyate satah \\ Ubhayor api dristo nats tw \\ Anayos tattwadarsibhih}

Terjemahannya : Apa yang tidak ada, tak akan pernah ada dan apa yang ada, tak akan berhenti ada. Orang yang melihat kebenaran sudah menarik kesimpulan bahwa apa yang tidak ada (badan jasmani) tidak tahan lama dan yang kekal (sang roh) tidak berubah. Inilah kesimpulan mereka setelah mempelajari sifat kedua-duanya.(II, 16)

Manusia memiliki pengetahuan tentang kebenaran dari kedua hal ini sepenuhnya antara yang nyata dan tidak nyata. Hanya dengan kenyataan yang kekal ini, kenyataan yang abadi, yang tak dapat dibatasi, tak dapat dihancurkan inilah dapat mengisi keseluruhan alam semesta ini. Hal ini sama dengan Diri yang ada pada manusia dan kenyataan yang ada di alam semesta ini.

"Orang yang tenang itu, meraskan sakit hati itu sama dengan kesenangan, tidak akan merasa terganggu olehnya, dan dia sendiri dapat mencapai keabadian" (II, 15). Karena kita tahu diri kita diri sendiri nyata, kita harus menghilangkan rasa kesenangan itu dan belajar untuk menyadari bahwa sumber utama kebahagiaan itu ada di dalam diri sendiri. "Bila orang mencampakkan semua keinginan yang ada dalam pikirannya dengan sepenuhnya, puas akan Diri sendiri, kemudian dia dikatakan sebagai orang yang memiliki kebijaksaan yang mantap" (II, 5).

Jnana yoga adalah proses yang sesungguhnya dari "Neti, Neti". "tidak ini, tidak itu". Inilah Diri yang semestinya tidak diperkenalkan dengan sesuatu yang benar-benar ada yang sifatnya sementara, seperti badan, pikiran dan perasaan dengan suatu objek atau sarana dari 
pengalaman itu. Bila orang telah mahir dalam melepaskan Dirinya yang sejati dari yang bukan Dirinya, dia akan dianugrahi penglihatan yang sesuai dengan milik Tuhan itu sendiri, dan pada permulaan sekali yang ada padanya adalah pengetahuan tentang Diri yang ada pada semua orang ada pada Diri itu.

Akan tetapi cara dengan ilmu pengetahuan dan cara perbedaan berikut ini tidaklah menunjukkan kelambatan atau pemberhentian aktivitas-aktivitas kehidupan yang normal. Apa yang perlu dilaksanakan oleh seseorang adalah menganggap badan itu sebagai rumah dimana orang itu tinggal, dan pikiran serta perasaan adalah sarana kehidupan dan terhadap semuanya itu Tuhanlah yang menjadi saksinya. Orang seperti itu tidak akan bertindak, tetapi dia tidak memperkenalkan Diri dalam tindakannya. Dia mengalami alam semesta secara objektif, bahkan telah mempelajari untuk melepaskan Dirinya dari pengalamannya. (Prabhavananda, 1995 :168-169)

\section{Karma Yoga}

Seorang individu yang telah mencapai pengetahuan dan perdamaian yang tertinggi, walaupun dia tidak memperoleh sesuatu dari perbuatannya, jika tidak ada sesuatu yang dihilangkan dari kemalasannya, bahkan pekerjaan, kendatipun dia sendiri bukan sebagai pelaku tetapi melalui latihan pikiran, perasaan dan badannya sebagai sarana mengenal Dirinya yang sejati dari alam semesta ini. Tidak pernah lupa akan Diri yang sejati, dia menyatu dengan kesadaran Tuhan selamanya, karena tahu bahwa hanya ada satu Tuhan yang ada pada semua orang, dia mengikutsertakan Dirinya denganTuhan dalam melayani umatnya. Sangat tenang, ditengah-tengah aktivitas yang bersemangat, itu adalah pengalaman dari orang yang kebijaksaannya sudah mantap. "Dia yang melihat kelambanan dalam bertindak dan bertindak dalam kelambanan, dia adalah orang pintar di antara orang-orang itu, dia adalah orang yogi dan pelaku dari segala tindakan" (IV, 18).

Jadi orang yang sudah sempurna itu, walaupun masih aktif dalam dunia yang sementara ini, dia menyatakan kesadarannya dengan Tuhan, dan Gita mengatakan, orang yang keinginannya telah sempurna mungkin dapat menyatu dengan Tuhan melalui aktivitas-aktivitas yang ada diluar dunia ini. Aktivitas-aktivitas inilah yang disebut dengan Karma Yoga. Pada bagian awal dari Gita, menceritakan betapa bingungnya Arjuna sebagai murid dalam memilih jalan dan tingkah laku yang benar, sehingga dia kembali menuju Krishna untuk meminta nasehat. Krishna, penjelmaan Tuhan, kemudian memberi tafsiran yang benar tentang ajaran-ajaran Upanisad. Penolakan, sebagai yang dia jelaskan, bukanlah penolakan dunia tetapi keduniawian, bukan perbuatan tetapi keinginan. Karma akan menuntun pada perbudakan, bila karma itu cenderung untuk menuruti keinginan dan membiarkan sifat aku (ego), karma itu akan menuntun pada kebebasan jika itu membantu menolak Diri itu atau membebaskan seseorang dari rasa kasih sayang terhadap perbuatannya. (Prabhavananda, 1995 :70-71)

Bila perbuatan dilakukan tanpa pamrih dan tanpa rasa keakuan, maka perbuatan itu dapat disebut Karma Yoga. Bila melakukan perbuatan dengan sikap itu, perbuatan itu menjadi yajna. Kehidupan didunia ini akan menjadi aman sentosa apabila tiap unsur yang menghuninya saling beryajna. Manusia beryajna pada alam dengan memeliharanya. Manusia harus penuh kasih sayang dan ikhlas berkorban, karena dengan demikian maka alam pun akan beryajna melimpahkan buahbuahan, umbi-umbian, daun-daunan, bunga dan yang lainnya kepada manusia dan makhluk hidup lainnya. Keikhlasan untuk berbuat secara sadar untuk berkorban demi tujuan yang lebih baik dan mulia. Demi persatuan, demi perdamaian dalam masyarakat dan negara, semua pihak harus menahan diri untuk tidak berbuat sekehendak hatinya yang bertentangan dengan kepentingan bersama. Hidup saling beryajna inilah akan dapat membuat dunia sebagai wadah kehidupan yang harmonis. (Sunetra, 2004:35-36). Kemudian bekerja dengan semangat pengorbanan, ini menjadi tapa atau penebusan dosa, dan menjadi yoga. Ketiga hal ini yajna, tapa dan yoga mempunyai pengertian yang sama. Setiap perbuatan yang dilakukan oleh manusia harus disucikan seperti itu. Bernafas pun adalah suatu perbuatan, tanpa 
melakukan karma manusia tidak dapat hidup sedetik pun didunia ini. Tetapi karma yang didasari oleh ego selalu akan sempit dan merusak, karena itu lakukanlah segala pekerjaan hanya dengan rasa pengorbanan dalam hatimu. Apakah hasilnya baik atau buruk, bermanfaat atau merugikan, tergantung pada jenis perbuatan yang dilakukan. Perbuatan itu sendiri tergantung pada perasaan. Selanjutnya perasaan itu tergantung pada pikiran. Dan pikiran tergantung pada makanan yang di makan. Karena itu urutannya adalah makanan menimbulkan pikiran, pikiran menimbulkan perasaan kemudian menimbulkan perbuatan dan akhirnya menimbulkan hasil. Hal ini Krishna berkata, "Curahkan seluruh perhatianmu untuk melakukan perbuatan yang baik dan jangan kau perhatikan hasilnya. Hasil akan timbul dengan sendirinya, tetapi engkau harus memusatkan pikiran pada perbuatannya”. (Sri Satya Sai Baba, 1991 : 350-35) Sri Ramakrishna, dewasa ini telah menjelaskan tafsiran Karma Yoga dan cita-cita penolakan dari kiasan yang terkenal tentang kapal yang ada di atas air.

"Biarlah kapal itu berada diatas air" dia berkata" tetapi janganlah diberikan air itu masuk ke kapal". Jadi biarkan orang itu hidup di dunia ini, tetapi jangan dibiarkan dunia itu menguasai Dirinya". Jadi yang ada di dunia, bukanlah karena dunia itu sendiri. Bekerja tetapi tidak terikat pada hasil dari perbuatan itu. "Bekerja bagimu adalah benar, tetapi tidak mengharapkan hasil daripadanya".

Upanisad mengajarkan bahwa ilmu pengetahuan sendiri dapat memeberikan kebebasan dan bahwa ilmu pengetahuan yang tak terhingga itu tersimpan dalam jiwa manusia. Alam dan Diri itu juga menunjukkan, bukan hanya keabadian dan kebahagiaan yang sempurna tetapi juga Chita atau Kesadaran yang murni. Ilmu pengetahuan yang tak terhingga itu, yang merupakan Diri itu sendiri, ditutupi oleh bayangan kebodohan dan juga karena hayalan manusia. Gita menjelaskan persoalan ini dengan mengajarkan rahasia dari pekerjaan itu. Bahwa kita harus bekerja dan tindakan akan membantu untuk mengungkapkan ilmu penegtahuan tentang Diri dengan menghilangkan kebodohan akan sifat aku itu. Salah satu maksud dan tujuan dari Karma Yoga adalah penyatuan Diri seseorang dengan Tuhan lewat perbuatan. Bukan melalui suatu perbuatan yang khusus yang benarbenar kita sempurnakan, tetapi melalui swadharma kita, yaitu suatu kewajiban khusus yang cocok dengan sifat-sifat kita dan nilainilai kemanusiaan yang dilakukan oleh manusia dan sebagai sarana untuk mencapai tujuan akhir. (Prabhavananda, 1995 : 70-72). Mengenai swadharma/kewajiban ini sudah jelas dinyatakan dalam BG (III.8) sebagai berikut:

\section{Niyatam kuru karma tvam Karma jyayo hy akarmanah Sarira-yatrapi ca te Na prasiddhyed akarmanah}

Terjemahan :

Lakukanlah tugas kewajibanmu yang telah ditetapkan, sebab melakukan hal demikian lebih baik daripada tidak bekerja. Seseorang bahkan tidak dapat memelihara badan jasmaninya tanpa bekerja.

\section{Raja Yoga}

Raja Yoga adalah praktek yang secara langsung menuju kepada penguasaan pikiran dan kesadaran. Sistem ini disebut juga royal yoga karena secara langsung menuntun sang yogi untuk mengontrol pikirannya (Kamajaya, 1998:24). Untuk mempelajari penggabungan dengan Tuhan lewat aktivitas, kita juga harus memiliki kesentosaan dan kedamaian yang diperoleh melalui meditasi. Sepanjang orang itu tak suka bersemedi, kedamaian itu tidak aka nada padanya. Gita menekankan pada latiha bersemedi yang secara teknis yang dikenal dengan Raja Yoga. Patanjali menjelaskan Raja Yoga sebagai suatu jalan yang terdiri atas delapan tahap, yaitu : Yama, Niyama, Asana, Pranayama, Pratyahara, Dharana, Dhyana,dan Samadhi. Gita tidak menjelaskan delapan langkah ini secara sistematis, akan tetapi langkah-langkah ini, ditunjukkan dengan ajarannya saat bersemadi. Penekanan ajarannyayang utama 
terletak pada penenangan pikiran yang resah dan meresapnya kesadaran-kesadaran itu dalam kesadaran Diri yang bersifat Ketuhanan. (Prabhavananda, $1995:$ 73)

"Dengan cara bagaimana dia bisa menghilangkan keresahan dan pikiran yang tidak mantap itu, menghindarinya, sehingga dia bisa menaklukkan Diri sendiri itu. Bawasannya kesadaran yang tinggi itu terdapat pada seorang Yogi yang berpikiran hening dan sempurna, yang tidak memiliki gejolak nafsu, yang suci dan yang telah menyatu dengan Brahman" (X, 26, 27). Seperti lampu, yang terletak pada suatu tempat yang terlindung oleh angin tidak akan berkedip, dan itu telah menjadi kiasan ynag dipakai oleh seorang Yogi yang pikirannya sudah dapat ditundukkan, dan konsentrasi tentang Dirinya sudah terlatih. Bila pikiran itu, benar-benar terkendali dengan latihan konsentrasi akan mencari ketenangan, dan dapat melihat Dirinya denga diri sendiri, orang akan merasa puas akan dirinya sendiri, bila dia merasa kebahagiaan yang tak terbatas itu, terutama bila dirasakan dengan pikiran yang telah disucikan dan terasamelebihi perasaan yaitu terjadi saat dia merasa tak pernah berpisah dari keadaan yang sebenarnya. Dan telah memperoleh suatu anggapan bahwa tidak ada kebahagiaan yang lain yang lebih tinggi dari kebahagiaan yang diperolehnya, dan saat kebahagiaan itu dirasakan dia bahkan tidak terpengaruh oleh kesedihan yang dalam, keadaan yang seperti ini dikenal dengan nama yoga, yaitu suatu keadaan yang terputus dari kontrak perasaan sakit. Yoga ini harus dilatih dengan ketekunan dan tidak terganggu oleh kemurahan hati. (VI, 19-23). (Prabhavananda, 1995 :74)

\section{Bhakti Yoga}

Bhakti Yoga adalah jalan kecintaan. Disini cinta difokuskan kepada Tuhan disepanjang waktu. Bhakti tidak diukur berdasarkan jumlah persembahan. Bhakti adalah masalah perwujudan cinta kasih di dalam hati. Tanda-tanda luar dari bhakti yang sejati adalah: kepercayaan, kerendahan hati dan keprihatinan. Kepercayaan adalah kemenangan akhir dari kebenaran dan cinta kasih.
Rendah hati dihadapan orang lain. Keprihatinan terhadap kejahatan. Bhakti tidak akan tumbuh dari luar diri manusia. Bhakti harus tumbuh dari dalam dengan usaha membersihkan mental (Kamajaya, 1998:21-22).

Pengetahuan bukanlah sejenis kepandaian yang mudah dimengerti dan bukan juga merupakan semadi yang ditujukan kepada suatu prinsip abstrak yang mudah dipahami, bahkan lebih dari itu, yaitu penunggalan tentang Dia (Tuhan) dan semadi yang ditujukan padanya, yang memiliki rasa atau penuh dengan kebahagiaan dan kecintaan pada Dirinya sendiri. Pengajaran cita-cita kerohanian sesungguhnya dapat dicapai pada saat suasana kegembiraan itu tidak disertai dengan kesedihan. Keesedihan itu sendiri yang mana bagi seorang calon, hanya dapat merupakan kesedihan yang terpisah dari Tuhan yang tercinta, dan juga merupakan kesedihan ynag diisi dengan kesenangan, karenanya selalu ada pengharapan akan penggabungan dengan sumber kesenangan dan cinta itu. (Prabhavananda, 1995 : 75)

Bhakti Yoga berarti selalu menyatu dengan Tuhan. Bhakti Yoga mengajarkan perlunya pengendalian pikiran dalam segala keadaan. Ia memaparkan ketegasan, tekad yang teguh untuk hanya mengamalkan ajaran spiritual dalam kehidupan sehari-hari, dan juga mengajarkan santrupti yaitu selalu merasa senang atau kegembiraan sejati. Bhakti Yoga juga menguraikan panjang lebar tentang pemujaan kepada Tuhan, baik dengan sifat maupun tanpa sifat, dengan wujud maupun tanpa wujud (Drucker, 1991:26). Gita membandingkan kedua macam pemujaan ini dan menunjukkan mana yang lebih baik, lebih mudah dan lebih aman bagi seorang bhakta pada tiap jenjang kemajuan spiritualnya. Gita menyatakan, tidak mungkinlah manusia mencapai tingkat tanpa sifat dan bentuk, sebelum ia melalui tahap memuja Tuhan dengan sifat dan wujud-Nya. Selama engkau masih memiliki keterikatan pada badan kasar dan masih tenggelam dalam kesadaran fisik, engkau tidak akan mampu memahami serta mencapai Yang Maha Tinggi yang tanpa sifat dan tanpa bentuk itu. Engkau akan dapat memuja yang tanpa wujud, bila engkau telah 
mampu mengatasi keterikatanmu, dengan raga, keterikatanmu dengan keduniawian, dan semua keterikatan lain. Karena itu, selama engkau menyamakan dirimu dengan badan dan beranggapan bahwa engkau mempunyai wujud tertentu, engkau tidak akan mencapai aspek Tuhan yang tanpa wujud (Drucker, 1991:27-28).

Dalam pemisahan hubungan dengan Tuhan, calon dan juga jiwa yang telah sempurna itu hidup dalam pemujaan terhadp Tuhan secara terus menerus. Bhakti yoga atau cara untuk mendekatkan Diri pada Tuha dengan jalan mencintai-Nya adalah pemujaan atau penyembahan secara terus menerus pada Tuhan, yang merupakan makhluk yang terdalam, Diri yang ada pada manusia dan perwujudan cinta dan segala sifat-sifat yang dianugrahkan. Ajaran Gita menekankan pada "kebaktian seluruh makhluk" kepada Tuhan, sebagai penyembah wajib mengingat intisari dari segala perlindungan dan kebahagiaan Tuhan seterusnya. Betapapun jahatnya penyembahan itu pada Aku, tanpa adanya kesayangan pada siapa pun, dan dia harus dianggap baik, karena dia benar-benar telah berubah. Dia segera akan menjadi orang Budiman dan mencapai kedamaian yang abadi. Sebenarnya tujuan dari pada Bhakti yoga atau semua yoga adalah penyerahan tanpa syarat dan menyeluruh dari sifat aku atau Diri yang lebih rendah pada Tuhan atau Diri yang tertinggi. Bila rintangan sifat ego itu bisa dihilangkan, apakah dengan mengikuti jalan dnegan ilmu pengetahuan, perbuatan kasih saying atau meditasi, dengans atucara atau dengan semua cara ini, Tuhan dari alam semesta ini Yang Maha Tahu, ada di mana-mana, dan yanga abadi itu, akan dinyatakan sebagai Tuhan yang ada dihati atau Diri yang tertinggi. (Prabhavananda, 1995: 76)

\section{SIMPULAN}

Bhagavad Gita adalah sebagai Pancamo Veda yang bersifat suplemen, ajarannya bersifat mistik dan rahasia,sehingga dikenal dengan kitab Gita Rahasia. Tidak hanya itu Bhagavad Gita juga merupakan kitab Yoga karena pokok-pokok ajaran di semua bab yang terdapat dalam Bhagavad Gita adalah ajaran Yoga itu sendiri. Bhagavad Gita terdiri dari kata Bhagavad dan Gitayang berarti "Lagu dari Tuhan". juga menyatakan bahwa yoga merupakansuatu keadaan yang bebas dari penderitaan dan kesedihan. Ada tiga rahasia yang terdapat dalam Gita yaitu yang pertama, seseorang harus melakukan semua tugasnya di dunia, meninggalkan semua ikatan untuk mendapatkan hasil dari tindakan kita. Yang kedua, seseorang harus membedakan antara dirinya dan yang bukan dirinya. Yang ketiga, seseorang harus menyadari bahwa semuanya yang ada, bergerak atau tidak bergerak, terlihat ataupun tidak terlihat, tiada bukan adalah Brahman. Bhagavad Gita menganjurkan empat jalan untuk mencapai kebebasan (moksa) terdiri dari: tindakan/perbuatan (Karma Yoga), meditasi (Raja Yoga), pengabdian dan cinta kasih (Bhakti Yoga), dan melalui pengetahuan (Jnana Yoga).

\section{Daftar pusaka}

Drucker, A.1991. Intisari Bhagavand-gita. Surabaya: paramita.

Kamajaya, Gede.1998. Yoga Kundalini. Surabaya: Paramita.

Narayana, Bhagavan Satya.1999. Pancaran Bhagavatam (Bagavata Vahini bagian 1) Surabaya: Paramita.

Prabvananda, Swami.1996. Amanat Bhagavadgita. Denpasar: Upada Sastra. 